\title{
SEISMIC BEHAVIOR OF STEEL REINFORCED ECC OR ECC/CONCRETE COMPOSITE SHORT COLUMNS
}

\author{
LI XU* ${ }^{*}$, JINLONG PAN ${ }^{\dagger}$ AND JINGMING CAI ${ }^{\dagger \dagger}$ \\ * Southeast University \\ Nanjing, China \\ e-mail: xuliyici@gmail.com \\ ${ }^{\dagger}$ Southeast University \\ Nanjing, China \\ e-mail: jinlongp@gmail.com \\ ${ }^{\dagger}$ Southeast University \\ Nanjing, China \\ e-mail: caijingming2016@163.com
}

Key words: ECC, composite short columns, seismic performance, optimal height

\begin{abstract}
Engineered cementitious composites (ECC) is an advanced composite material with strain hardening and multiple cracking behaviors. For a reinforced concrete short column, substitution of conventional concrete with ECC can significantly improve the deformation and energy dissipation ability. In this paper, it is proposed that concrete in the bottom region (plastic hinge region) of short columns is substituted with ECC to form ECC/RC composite short columns to improve the seismic performance and economic efficiency. Firstly, two ECC/RC composite short columns, one ECC short column and one RC short column were tested under reversed cyclic loading. The influence of shear reinforcement ratio of the composite columns was investigated as well. Then, a finite element analysis with the software of ATENA was carried out to obtain the optimal height of the ECC layer in the ECC/RC composite column. The mechanical behaviors of RC short column, ECC short column and ECC/RC composite short columns with different heights of ECC layers under combined vertical and horizontal loading were comprehensively studied and compared. The experimental results indicate that the use of ECC in the column bottom can change the failure mode from brittle flexure-shear failure to ductile flexure failure mode. The ECC and ECC/RC composite short column are extremely similar in seismic performance, and have superior ultimate load capacity, ductility and energy dissipation capacity to the RC short column. Due to higher shear strength, ECC can partly replace stirrups and reduce the stirrup ratio of ECC/RC composite short column. The simulation results show that the ECC/RC composite short column, where the ECC layer is $0.8 \mathrm{~h}$ (h is the depth of the column section) height, can achieve similar mechanical properties of ECC short column. And the ECC zone in this composite column is just the plastic hinge regions of the $\mathrm{RC}$ short column.
\end{abstract}




\section{INTRODUCTION}

In recent decades, the investigation of conventional reinforced concrete frame structures has indicated that the seismic damage of bearing columns tended to be more serious than other components. In order to prevent the building from collapse, satisfactory inelastic deformation and carrying capacity of columns are urgently expected. However, due to the brittle nature of concrete, the usage of concrete columns in seismically active regions, where enough ductility and energy dissipation capacity are required to resist seismic forces, poses a challenge. These concrete columns always exhibited brittle failures, especially in concrete short columns where shear dominates the behavior. Furthermore, concrete is a kind of brittle material with low tensile strength, which easily results in spalling of the concrete cover in concrete structures during an earthquake. Spalling of the concrete cover is usually associated with a decrease in bonding between the steel bars and the surrounding concrete, and degradation of the column's stiffness. To address these problems, there are generally two approaches that have been proposed as practical and effective solutions. The first approach is to employ materials such as steel and fiberreinforced polymer (FRP) to externally confine the concrete columns. Steel or FRP confined concrete columns have two forms for application. One is concrete filled tube (steel or FRP) column that is mainly applied in new structures, the other is steel or FRP externally jacketed or wrapped concrete column that is mainly used in retrofit of existing structures. The seismic performance of steel-confined concrete columns [1-4] and FRP-confined concrete columns [5-8] has been studied extensively. These confined concrete columns exhibit better ductility and energy dissipation capacity than ordinary reinforced concrete columns, but are very poor in fire resistance. For certain applications, the jacketed or wrapped techniques are employed to increase the fire resistance, but they are normally cumbersome and expensive. Moreover, for steel confined concrete columns, it is very troublesome in joint connection and not very durable due to steel corrosion. For concrete filled FRP tube columns, complicated connection methods must be adopted between FRP tube and concrete, which leads to great reduction of concrete casting quality.

The second approach is to use fiber reinforced concrete or cement composites (FRCCs) to substitute concrete in the reinforced concrete columns. Different types of fibers, such as steel, polymeric, glass, and carbon fiber, have been evaluated for structural applications [9]. Experimental results from steel fiber reinforced concrete columns indicated that steel fiber reinforcing effect on these columns was more effective in improving the strength and ductility capacity than the stiffness and energy capacity [10]. Billington and Yoon [11] applied a ductile fiber-reinforced cement composite (DFRCC) in the precast columns at potential plastic hinging regions and found that using DFRCC allowed the column to dissipate more hysteretic energy than traditional concrete. Osorio et al. [12] tested the synthetic fiberreinforced concrete (SNFRC) columns with reversed cyclic loads, which indicated that SNFRC columns outperformed normal concrete columns in ductility and energy dissipation, and the larger the amount of transverse reinforcement the smaller the influence of the fibers on the column's behavior.

In recent years, a high performance fiber reinforced cementitious composites called engineered cementitious composite (ECC) has been developed for applications in construction industry [13-15]. It has the similar range of tensile (4-6MPa) and compressive strengths (30-80MPa) as concrete. The most prominent property of ECC is the multiple cracking and pseudo strain hardening in tension. It behaves as, after first cracking, the tensile load capacity of ECC continuing to improve with increase of the tensile strain up to $3-5 \%$, accompanying by the formulation of multiple tiny cracks [16]. By contrast, concrete fails in a brittle manner once its tension strength is reached. In compression, ECC also has the increased ultimate strain compared with concrete [17]. These enhanced ultimate strains in tension and compression 
endow ECC an ultra-ductile behavior, which is complete lack in conventional concrete. Thus, substitution of concrete with ECC in concrete structures may solve the deficiencies associated with the brittleness of concrete.

Some experiments have found that the strain of tensile reinforcement in ECC members can linearly increase with the applied loading up to yielding [18]. It also has been proved that compatible deformation can be achieved between ECC and tensile reinforcements, which eliminates the bond and cover splitting [19]. ECC beam showed better seismic performance compared with concrete beams. The ECC beams failed in shear showed more significant improvement than those failed in flexure [20]. Experimental results of ECC columns and frames from Fisher et al indicated that the application of ECC could improve structure integrity at various stage [21, 22]. Experiments on the ECC beam-column joints confirmed that ECC could partly replace the shear resistance of stirrups in the joints, resulting in the decreased amount of stirrups $[23,24]$.

This paper firstly reports on the seismic behaviors of ECC and ECC/RC composite short columns from the reversed cyclic load test, and the concrete column is served as counterpart. The influence of transverse reinforcement ratio on the composite columns is presented and discussed. Then, in order to ensure the cost-effectiveness, this paper studied the optimal height of the ECC layer in the ECC/RC composite column by a finite element analysis with the software of ATENA. The RC short column, ECC short column and ECC/RC composite short columns with different heights of ECC layers were numerically simulated under combined vertical and horizontal loading.

\section{EXPERIMENTAL PROGRAM}

\subsection{Preparation of specimens}

In this study, the column specimens were tested to study the seismic behaviors of ECC and ECC/RC composite short columns. The shear span ratio of the column specimens was 2.0, including a RC column (S1), an ECC column (S2) and two ECC/RC composite columns with different transverse reinforcement ratios (S3 and S4). For the ECC/RC composite columns, ECC material was mostly cast in the bottom part with the height of $300 \mathrm{~mm}$ from the top of the foundation beam. To avoid weakening the interface between column and foundation beam, ECC material was also cast in the connection part of the foundation beam, as shown in Fig. 1. The specimen information can be seen in Table 1 .

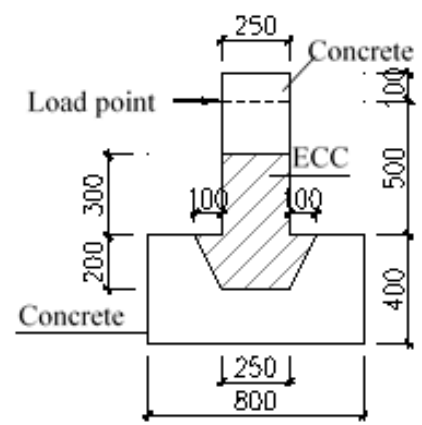

Figure 1: Casting range of ECC and detailed dimensions of column specimens.

Table 1: Summary of specimen information

\begin{tabular}{ccccc}
\hline Specimen & Composite & Shear span ratio & Axial compression ratio & $\rho_{\text {sv }}(\%)$ \\
\hline S1 & RC & 2.0 & 0.60 & 1.78 \\
\hline S2 & ECC & 2.0 & 0.60 & 1.78 \\
\hline S3 & ECC/RC & 2.0 & 0.60 & 1.78 \\
\hline S4 & ECC/RC & 2.0 & 0.60 & 0.89 \\
\hline
\end{tabular}

Note: $\rho_{\mathrm{sv}}=$ transverse reinforcement ratio of columns.

Fig. 1 also shows the detailed dimensions of the column specimens. All the column specimens had the same cross section as $250 \mathrm{~mm} \times 250 \mathrm{~mm}$. Four $16 \mathrm{~mm}$-diameter steel 
bars were used as the longitudinal reinforcement, and $8 \mathrm{~mm}$-diameter steel bars were used as the shear reinforcement with the spacing of $150 \mathrm{~mm}$ or $75 \mathrm{~mm}$. For each column specimen, a large beam with cross section of $400 \mathrm{~mm} \times 300 \mathrm{~mm}$ was used to provide fix constraint of the column at the base. In the large foundation beam, four 20mm-diameter steel bars were used as the longitudinal reinforcement, and $8 \mathrm{~mm}$-dimeter steel bars were used as shear reinforcement with the spacing of $90 \mathrm{~mm}$.

\subsection{Material properties}

To evaluate the ductility behavior of ECC used for casting the specimens, uniaxial tension tests were conducted, and indicated that the tensile strength of ECC reached $5 \mathrm{MPa}$ and the ultimate tensile strain approached 4\%. A number of cubic specimens with dimension of $100 \times 100 \times 100 \mathrm{~mm}$ were prepared with concrete and ECC used in the specimens, and tested in compression. The compressive strength of concrete and ECC are 38.19 and $30.56 \mathrm{MPa}$, respectively. All the reinforcing bars have the similar yield strength. Table 2 summarizes the material properties of the steel reinforcement that were obtained from the direct tension tests.

Table 2: Material properties of steel reinforcement

\begin{tabular}{ccccc}
\hline $\begin{array}{c}\text { Diameter } \\
/ \mathrm{mm}\end{array}$ & Area $/ \mathrm{mm}^{2}$ & $\begin{array}{c}\text { Yield strength } \\
/ \mathrm{MPa}\end{array}$ & $\begin{array}{c}\text { Ultimate strength } \\
/ \mathrm{MPa}\end{array}$ & $\begin{array}{c}\text { Elasticity modulus } \\
/ \mathrm{GPa}\end{array}$ \\
\hline 8 & 50.3 & 467.5 & 610.0 & 200 \\
\hline 16 & 201.1 & 462.5 & 607.5 & 200 \\
\hline 20 & 314.2 & 462.5 & 602.5 & 200 \\
\hline
\end{tabular}

\subsection{Test setup and loading process}

In the experiments, each column specimen was loaded by a horizontal hydraulic actuator fixed on the reaction wall. The column specimen was fixed on the ground with two vertical steel anchors. To avoid horizontal displacement of the foundation beam during the loading process, a number of steel blocks were placed between the foundation beam and the reaction wall and two high strength steel strands were used to fasten the foundation beam with the reaction wall. The loading point is $500 \mathrm{~mm}$ away from the column base for the columns. Before the horizontal loading was applied, a constant axial load was applied on the top of column specimen by a hydraulic jack. A pulley with rollers was installed between the hydraulic jack and the reaction steel beam to reduce friction between the hydraulic jack and the reaction steel frame. The loading system is shown in Fig. 2.

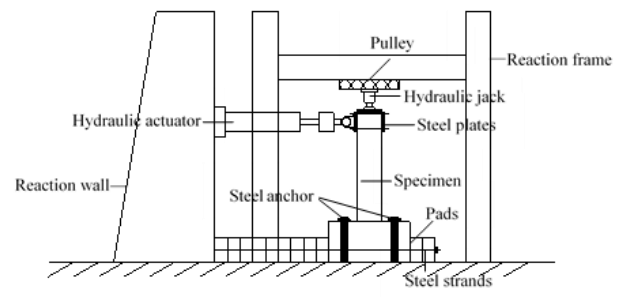

Figure 2: Test setup for all specimens.

Each column specimen was tested under reversed cyclic loading with displacement increments. For each displacement increment, two loading cycles were conducted. The loading history is shown in Fig. 3. The test was terminated when the residual load capacity of the specimen decreased to $85 \%$ of the peak load. To investigate the strain variation of steel reinforcement, a number of strain gauges were attached on the reinforcement surface to collect the strain values during the loading process. For each column specimen, the distributions of strain gauges are shown in Fig. 4. A linear variation displacement transducer (LVDT) was installed externally to the foundation beam to measure the displacement in the horizontal 
direction.

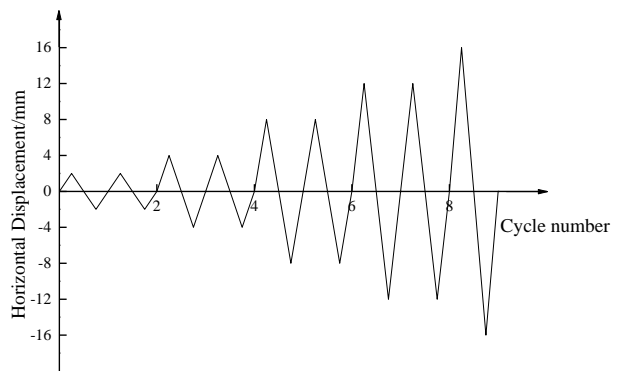

Figure 3: Loading history for all specimens.

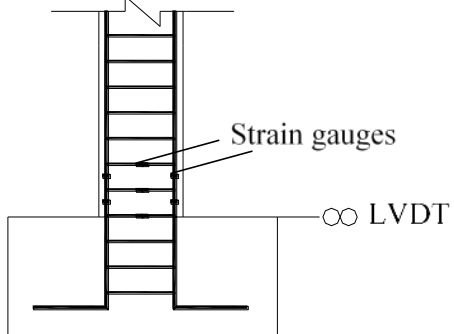

Figure 4: Position of the strain gauges and LVDT.

\section{EXPERIMENTAL RESULTS AND DISCUSSIONS}

\subsection{Failure mechanism and characteristics}

The crack and failure patterns for all column specimens are shown in Fig. 5. Among all short column specimens, only Specimen S1 failed in flexure-shear mode. Specimen $\mathrm{S} 1$ is a control reinforced concrete column specimen. With increasing external loading, more and more diagonal cracks occurred at the base of the RC column Specimen S1, and finally it failed by severe concrete spalling with continuous opening of shear cracks, leading to exposure of stirrups and longitudinal reinforcement at the base of the column. Specimen S2 is a steel reinforced ECC column, and $\mathrm{S} 3$ and $\mathrm{S} 4$ are both ECC/RC composite columns only with different shear reinforcement ratios. Specimens S2-S4 all failed in flexural mode with multiple fine cracks around the bottom region and a major horizontal crack at the base of the column. Specimen S4 also exhibited flexural failure although the amount of the applied shear reinforcement is only half of that of Specimen S2 and S3, indicating that application of ECC material for the whole column or for the bottom region of the column can significantly increase the shear strength of column specimen, and can avoid flexure-flexure-shear failure of the short column. Due to reduction of the stirrups in Specimen S4, more fine diagonal cracks appeared around the bottom region of the column, but no obvious drop in load carrying capacity or ultimate displacement was noticed.

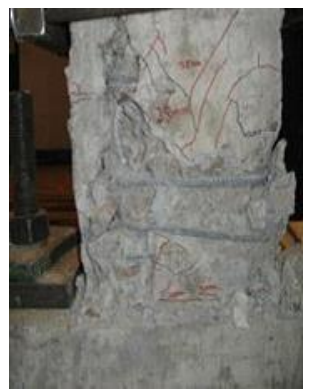

(a) S1

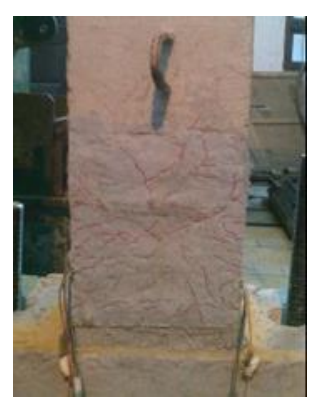

(a) S3

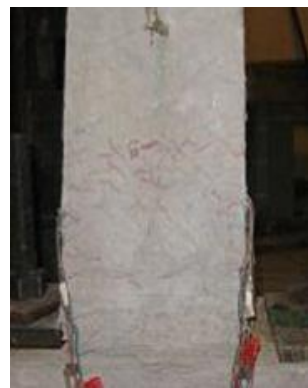

(b) S2

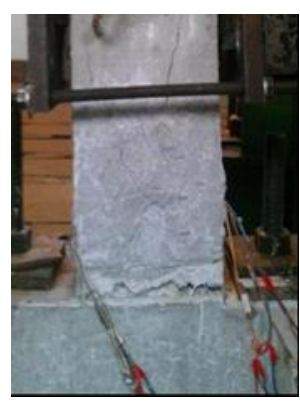

(b) S4
Figure 5: Crack patterns of specimens after failure.

\subsection{Hysteresis loops}

Hysteresis loops describe the curves of cyclic load versus lateral displacement. Fig. 6 shows the hysteresis loops for all column specimens. Specimen S1 failed in shear mode, and the hysteresis loops showed obvious pinching effect, indicating that brittle failure occurred for Specimen S1 and the energy absorption was relative low compared with Specimens S2-S4. At the later stage of the loading process, the pinching effect of $\mathrm{S} 1$ became more serious due to the development of shear cracks, which led to a rapid drop in the lateral stiffness. Specimen S2 showed much more stable and full hysteresis loops than Specimen S1. In addition, S2 maintained more loops under cyclic loads, exhibiting higher 
plastic deformation capacity. It should be noted that though Specimen S2 had a slight increase in energy dissipation compared with specimen S3 and S4, the three specimens exhibited very similar hysteresis loops and ultimate displacement and were superior to Specimen S1. This indicates that application of ECC in the short column can change the failure mode from brittle flexure-shear failure to ductile flexural failure, and improve the seismic performance of the column even with reduced amount of stirrups. Compared with Specimen S2, which is a reinforced ECC column, the ECC/RC composite columns (S3 and S4) showed similar hysteresis loops, indicating that application of ECC only in the bottom region can have the same seismic performance as the reinforced ECC column.

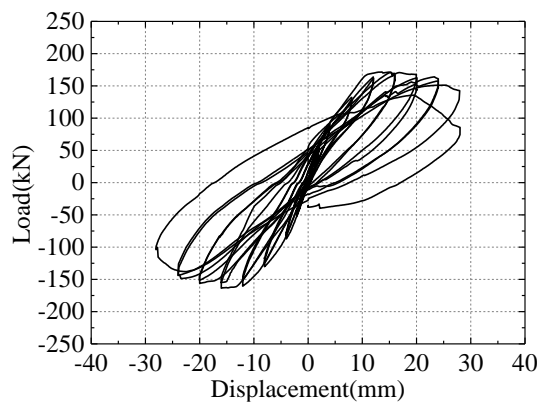

(a) $\mathrm{S} 1$

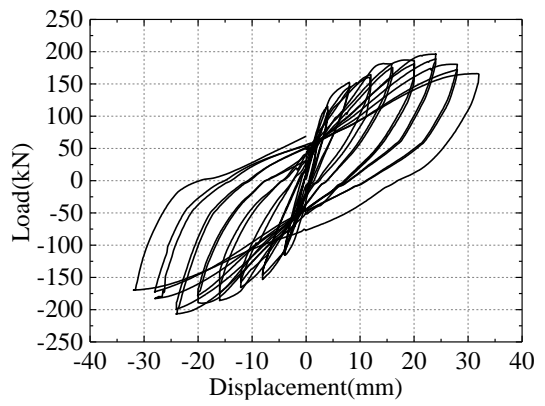

(b) S2

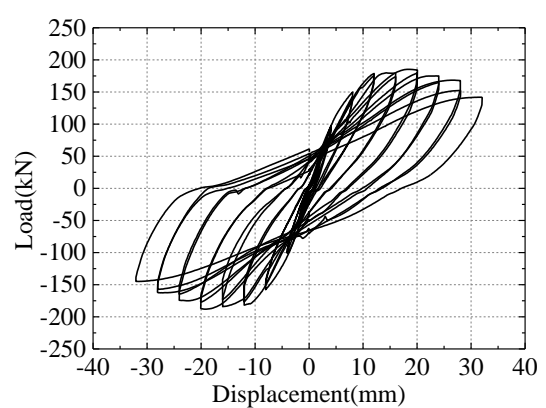

(c) S3

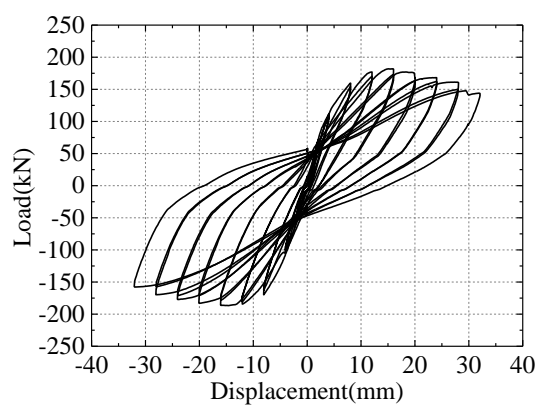

(d) $\mathrm{S} 4$

Figure 6: Hysteresis loops for each specimen.

\subsection{Skeleton curve and ductility}

Fig. 7 shows the skeleton curve for each column specimen, which is the envelope curve of peak load point for each loading cycle. Based on the displacement values obtained from the skeleton curves, ductility coefficient $(\mu)$ of each column specimen can be calculated as Eq. (1):

$$
\mu=\Delta_{u} / \Delta_{y}
$$

Where $\Delta_{\mathrm{y}}$ is the yielding displacement and $\Delta_{\mathrm{u}}$ is the ultimate displacement when the applied load declines to $85 \%$ of the peak load. It is often used to evaluate the ductility performance of structural members, and is shown in Table 3.

Fig. 7 shows the skeleton curve of each column specimen. The curve of RC column Specimen S1 tended to drop more quickly due to the premature flexure-shear failure of the column. The curves of ECC and ECC/RC composite columns (S2, S3 and S4) dropped more gently due to flexural failure of the columns. The application of ECC in Specimen S2, S3 and S4 increased the ultimate load capacity and displacement compared with $\mathrm{S} 1$.

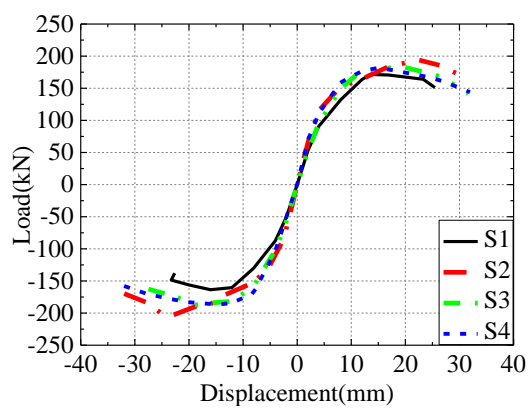

Figure 7: Skeleton curves for each specimen. 
Table 3: Displacement values and ductility coefficients of specimens

\begin{tabular}{|c|c|c|c|c|c|c|c|c|}
\hline \multirow{2}{*}{ Specimen } & \multirow{2}{*}{$\rho_{\mathrm{sv}}(\%)$} & \multicolumn{2}{|c|}{ Yielding load } & \multicolumn{2}{|c|}{ Peak load } & \multicolumn{2}{|c|}{ Ultimate load } & \multirow{2}{*}{$\begin{array}{c}\text { Ductility } \\
\text { coefficient }\end{array}$} \\
\hline & & $\mathrm{P}_{\mathrm{y}} / \mathrm{kN}$ & $\Delta_{\mathrm{y}} / \mathrm{mm}$ & $\mathrm{F}_{\mathrm{p}} / \mathrm{kN}$ & $\Delta_{\mathrm{p}} / \mathrm{mm}$ & $\mathrm{F}_{\mathrm{u}} / \mathrm{kN}$ & $\Delta_{\mathrm{u}} / \mathrm{mm}$ & \\
\hline S1 & 1.78 & 143.50 & 9.48 & 163.67 & 16.08 & 139.12 & 26.34 & 2.78 \\
\hline S2 & 1.78 & 0 & 9.51 & 206.64 & & 175 & & \\
\hline S & 78 & & 9. & 29 & & 15 & & \\
\hline S4 & 0.89 & 156.69 & 7.83 & 181.88 & 15.07 & 154.59 & 28.83 & 3.68 \\
\hline
\end{tabular}

The ductility coefficients of the short column specimens ranged between 2.78 and 3.68. The ductility coefficients of Specimens S2, S3 and $\mathrm{S} 4$ were higher than that of $\mathrm{S} 1$ due to the transformation in failure mode from flexureshear failure (S1) to flexural failure (S2, S3 and S4).

\subsection{Deterioration of load capacity}

In order to estimate the variation of load capacity of specimens at each load level, a parameter $\lambda_{i}$ called deterioration coefficient of load capacity is established as Eq. (2):

$$
\lambda_{i}=V_{i, 1} / V_{i, 2}
$$

Where $V_{i, 1}$ and $V_{i, 2}$ are the peak load respectively corresponding to the first and second hysteresis loop in the $\mathrm{i}^{\text {th }}$ cyclic loading. The calculation results are shown in Table 4.

Table 4: Deterioration of load capacities of Specimens

\begin{tabular}{ccccccccc}
\hline Specimen & $2 \mathrm{~mm}$ & $4 \mathrm{~mm}$ & $8 \mathrm{~mm}$ & $12 \mathrm{~mm}$ & $16 \mathrm{~mm}$ & $20 \mathrm{~mm}$ & $24 \mathrm{~mm}$ & $28 \mathrm{~mm}$ \\
\hline S1 & 0.9798 & 0.9504 & 0.9664 & 0.9611 & 0.9653 & 0.9603 & 0.9652 & 0.9214 \\
\hline S2 & 0.9556 & 0.9665 & 0.9570 & 0.9613 & 0.9549 & 0.9548 & 0.9654 & 0.9501 \\
\hline S3 & 0.9587 & 1.0003 & 0.9519 & 0.9763 & 0.9542 & 0.9547 & 0.9510 & 0.9451 \\
\hline S4 & 1.0017 & 0.9797 & 0.9645 & 0.9711 & 0.9528 & 0.9585 & 0.9653 & 0.9483 \\
\hline
\end{tabular}

Table 4 illustrates that the deterioration of load capacity of the specimens followed a similar trend and, except for the sudden drop observed in the load capacity of the RC short column Specimen S1 at the displacement of 28 $\mathrm{mm}$. The sudden drop observed in S1 was caused by the wide shear cracks and severe concrete spalling.

\subsection{Column stiffness}

Fig. 8 illustrates the variation of column stiffness (K) with horizontal displacement for each specimen. Column stiffness $(\mathrm{K})$ is defined as the slope of the line joining positive peak load and negative peak load of the first hysteresis loop at per load level. It can be calculated by Eq. (3):

$$
K=\left(\left|+F_{i}\right|+\left|-F_{i}\right|\right) /\left(\left|+\Delta_{i}\right|+\left|-\Delta_{i}\right|\right)
$$

Where $+\mathrm{F}_{\mathrm{i}}$ is the positive peak load and $-\mathrm{F}_{\mathrm{i}}$ is the negative peak load of the first hysteresis loop at per load level, $+\Delta_{\mathrm{i}}$ and $-\Delta_{\mathrm{i}}$ are the corresponding displacements.

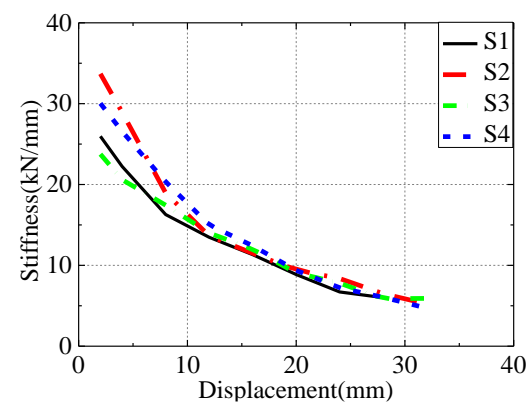

Figure 8: Stiffness-displacement curves for each specimen.

The column stiffness of each specimen progressively decreases with increasing horizontal displacements, which is associated 
with the cracking of concrete and yielding of steel reinforcement. The reduction in stiffness of short column specimens was most significant up to $8-10 \mathrm{~mm}$. And beyond these displacements stiffness degradation continued at a lower and continually decreasing rate. When reaching the termination of the curve, the slope of the curve progressively approaching zero in majority of the specimens.

Although ECC has a lower elastic modulus compared with concrete, the stiffness of ECC and $\mathrm{ECC} / \mathrm{RC}$ composite columns was not less than that of RC columns, especially Specimen S2, the stiffness of which was even higher than its companion Specimen S1. This is because during the loading process, multiple tiny cracks appeared in ECC and ECC/RC composite columns, while wide cracks were observed in $\mathrm{RC}$ columns. The effective moment of inertia of $\mathrm{ECC}$ and ECC/RC composite columns were much higher compared with RC columns, which enables the similar stiffness between all column specimens.

\subsection{Energy dissipation}

The energy dissipation capacity of each specimen was evaluated by cumulative energy dissipation. It is defined as the sum of the areas of each hysteresis loop before the failure load level. Fig. 9 shows the cumulative energy dissipation curves for each specimen.

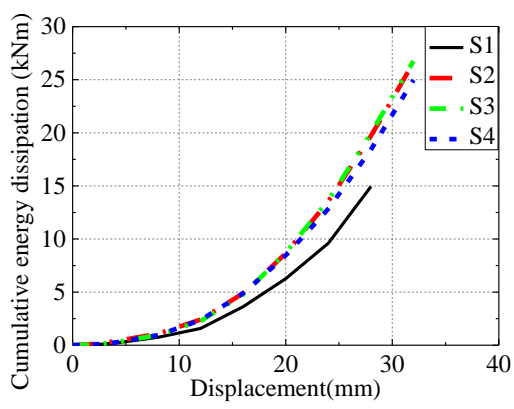

Figure 9: Cumulative energy dissipationdisplacement curves for each specimen.

In Specimen S1, a $43.88 \%$ decrease in cumulative energy dissipation was measured in ultimate displacement compared with Specimen S2. This is because the brittle flexure-shear failure in S1, which strongly limited the plastic deformation. For Specimens S3, which were ECC/RC composite columns with normal transverse reinforcement, no drop was observed in the cumulative energy dissipation compared with ECC column Specimens S2, indicating that ECC/RC composite column is adequate for the desired energy dissipation capacity. The comparison of the cumulative energy dissipation of Specimens S3 and S4, which were only different in stirrup ratios, showed that at a same displacement level, the columns exhibited very similar energy dissipation capacities. It indicates that the stirrup ratio can be reduced in ECC and ECC/RC composite columns since ECC can bear more shear loads than concrete.

\subsection{Strain analysis}

The variation of steel reinforcement strains was recorded by strain gauges placed on the steel reinforcement at different locations. The values given in Fig. 10 represent the recorded displacements of specimens that were obtained at the start of longitudinal reinforcement yielding.

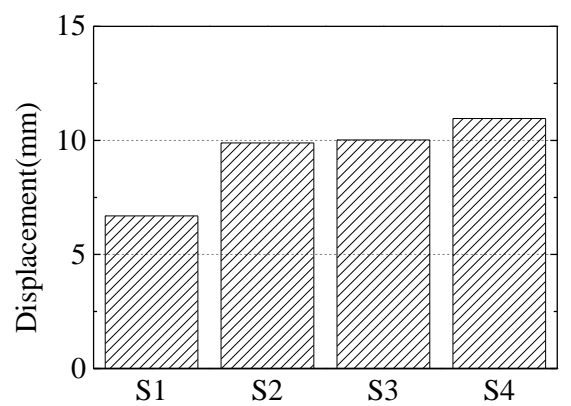

Figure 10: Yielding displacements of longitudinal reinforcement for each specimen.

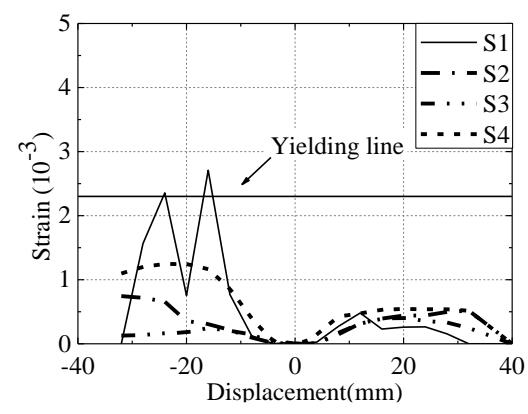

Figure 11: Strain-displacement curves of stirrup for each specimen. 
The longitudinal reinforcement in Specimen $\mathrm{S} 1$ first yielded at the displacement of $6.69 \mathrm{~mm}$, which was much less than that of the other three short column specimens due to wide opening of shear cracks in RC column. It is attributed to the combined influence of the fibers in ECC that can bridge and restrain the cracks and compatible deformation between steel reinforcement and ECC, which eliminates bond splitting cracks and cover splitting. The reinforcement stresses in ECC and ECC/RC composite columns were much less than that in $\mathrm{RC}$ column, leading to the delay of reinforcement yielding. Fig. 11 shows the variation of stirrup strain versus displacement for each specimen. It was obvious that only the stirrups in Specimens S1 yielded before reaching ultimate displacement.

\section{FINITE ELEMENT ANALYSIS}

\subsection{Constitutive Model}

In this work, the software ATENA is employed for FE simulations. ATENA has been proved to be suitable for nonlinear analysis of concrete and ECC members [25]. In ATENA, the cementitious materials are modeled by fracture-plastic constitutive model. Fractureplastic model combines constitutive models for tensile (fracturing) and compressive (plastic) behavior. The fracture model is based on the classical orthotropic smeared crack formulation and crack band model. It employs Rankine failure criterion, exponential softening, and it can be used as rotated or fixed crack model. The hardening/softening plasticity model is based on Menétrey-Willam failure surface. Besides, the model can be used to simulate concrete cracking, crushing under high confinement, and crack closure due to crushing in other material directions [26]. There are several ATENA material models based on the fracture-plastic constitutive model. In this work, the material of "CC3D Nonlinear Cementitious 2" is chosen to simulate concrete and the material of "CC3D Nonlinear Cementitious 2 User" is chosen for ECC. The two materials are very similar and assume a hardening regime before the compressive strength is reached. The uniaxial stress-strain curves of concrete and ECC are shown as Fig. 12 and Fig. 13, and the corresponding parameters are listed in Table 5.

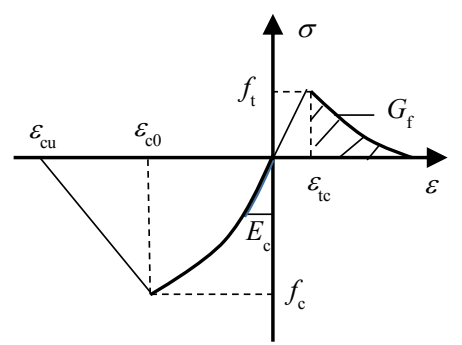

Figure 12: Stress-strain relationship of concrete.

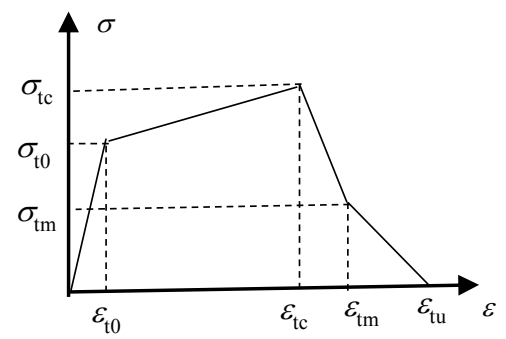

(a) Under uniaxial tension

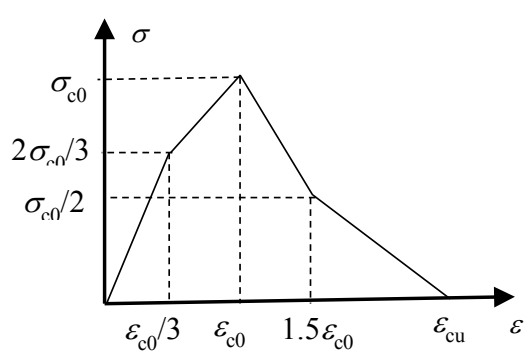

(b) Under uniaxial compression

Figure 13: Stress-strain relationship of ECC.

Table 5: Material properties of concrete and ECC

\begin{tabular}{|c|c|c|c|c|c|c|c|c|c|c|}
\hline \multirow{2}{*}{ Concrete } & \multicolumn{2}{|c|}{$f_{c} / \mathrm{MPa}$} & $\varepsilon_{c 0}$ & $\varepsilon_{c u}$ & $\mathrm{E}_{\mathrm{c}} / \mathrm{GPa}$ & $f_{t} / \mathrm{MPa}$ & \multicolumn{2}{|c|}{$G_{f} /(\mathrm{N} / \mathrm{m})$} & & \\
\hline & \multicolumn{2}{|c|}{38.19} & 0.002 & 0.006 & 33.42 & 2.72 & & 8.06 & & \\
\hline \multirow{2}{*}{ ECC } & $\sigma_{t 0} / \mathrm{MPa}$ & $\varepsilon_{t 0}$ & $\sigma_{t c} / \mathrm{MPa}$ & $\varepsilon_{t c}$ & $\sigma_{t m} / \mathrm{MPa}$ & $\varepsilon_{t m}$ & $\varepsilon_{t u}$ & $\sigma_{c 0} / \mathrm{MPa}$ & $\varepsilon_{c 0}$ & $\varepsilon_{c u}$ \\
\hline & 3.2 & 0.0021 & 4.5 & 0.03 & 1.5 & 0.05 & 0.06 & 38.19 & 0.004 & 0.012 \\
\hline
\end{tabular}


The steel reinforcement is described by a bilinear curve with strain hardening (Fig. 14). The yield and ultimate strength is 460 and 600 $\mathrm{MPa}$ respectively. The elasticity modulus is 200GPa and the ultimate strain is assumed to be 0.08 .

The formula recommended by CEB-FIP Model Code 1990 [27] is adopted to model the bond stress-slip relationship between matrix and the steel reinforcement, as shown in Fig. 15.

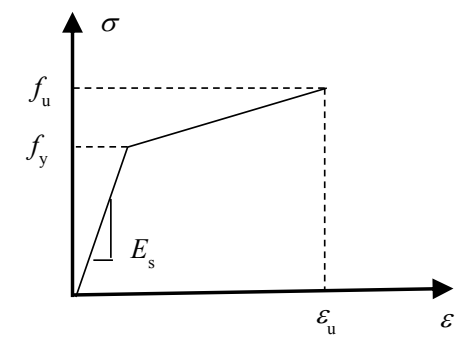

Figure 14: Stress-strain relationship of steel bars.

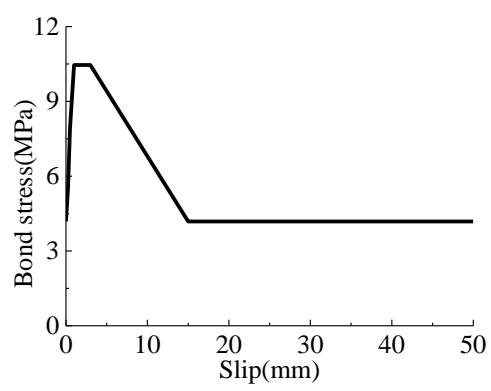

Figure 15: Bond-slip behavior between steel reinforcement and matrix.

\subsection{Finite element model}

One RC short column, One ECC short column and several ECC/RC short columns with different heights of ECC layers are simulated herein using the above described constitutive models. The dimensions, reinforcements and loading positions of the columns are the same as the column specimens $\mathrm{S} 1$ and $\mathrm{S} 2$ tested in the experiment. A monotonic horizontal loading and a constant vertical loading are applied on the columns. The axial compression ratio is 0.6 .

Three-dimensional finite element models are adopted to simulate the columns. In this analysis, the brick solid elements are used for concrete and ECC. The truss elements are used for steel reinforcement. The spring elements are used to consider the bond behavior between the steel bars and the concrete or ECC. Perfect bond between concrete and ECC is assumed in the finite element analysis. The columns are loaded with displacement control during the loading process. The "Newton- Raphson" iterative procedure is selected as the solution method. Both displacement and residual convergence criteria are adopted in the computation and the error tolerance is set to be 0.01 .

\subsection{Calculation results and discussion}

For the RC short column, it fails due to the flexure-shear failure of the concrete. The longitudinal reinforcement of the RC short column yields firstly, afterwards the transverse reinforcement yields. For the ECC short column, it exhibits flexure failure. The ultimate strength and displacement of ECC short column are much larger than that of RC short column.

In order to find the critical zone or plastic hinge region where ECC should be applied, the evolution of the internal strain and deformation of the RC short column are investigated and the results are shown in Fig.16- Fig.18. Fig. 16 exhibits the distribution of the steel tensile strain of the RC short column. It is observed from the figure that although the steel strain increases as the horizontal displacement increases, the maximum length of the steel yielding zone is limited to a certain value. The steel yielding zone is defined as the region where the steel in tension has reached or exceeded its yield stress. The maximum length of the steel yielding zone is between 194 and $199 \mathrm{~mm}$, and is approximately equal to $0.8 \mathrm{~h}$ (h is the depth of the column section).

Similar conclusion can be reached in the distribution of sectional curvature of the RC short column, as Fig.17 shows. The region where the sectional curvature has reached or exceeded the yielding curvature (yielding curvature: $0.0239 / \mathrm{m}^{-1}$ ) is also limited to a certain value. The value is about $198 \mathrm{~mm}$ or $0.8 \mathrm{~h}$.

The distribution of concrete compressive strain is shown in Fig.18. The concrete crushing zone where the concrete strain is greater than 
0.002 (strain at peak concrete strength) is investigated. The zone stabilizes at a certain value after the ultimate displacement is reached. The value is about $290 \mathrm{~mm}$, and is close to $1.2 \mathrm{~h}$.

Since the critical zone or plastic hinge region of $\mathrm{RC}$ short column is about $0.8 \mathrm{~h}$ or $1.2 \mathrm{~h}$ height, strategic application of ECC in this region can most effectively increase its mechanical behaviors. To confirm this view, five $\mathrm{ECC} / \mathrm{RC}$ composite short columns, whose height of ECC layer is $0.4 \mathrm{~h}, 0.6 \mathrm{~h}, 0.8 \mathrm{~h}, 1.0 \mathrm{~h}, 1.2 \mathrm{~h}$ respectively, are studied and compared with RC and ECC short column. Fig. 19 shows the loaddisplacement curves of the calculated columns.

It is found in the figure that the ultimate strength and displacement of the short columns increase with the height of the ECC layer. However, compared with RC short column, when the heights of ECC layers are $0.4 \mathrm{~h}$ and $0.6 \mathrm{~h}$, the enhancement in mechanical behaviors of the composite short columns is very limited. When the ECC layer reaches $0.8 \mathrm{~h}$, an obviously increase can be found in the ultimate strength and displacement. The load-displacement curve of this column, of which the ECC layer is $0.8 \mathrm{~h}$ height, is extremely similar to that of the ECC short column. And an additional increase in the usage of ECC in this ECC/RC composite short column would make no sense in the mechanical behaviors. It indicates that the optimal height of the ECC layer is $0.8 \mathrm{~h}$. And the ECC zone is just the plastic hinge regions of the RC short column.

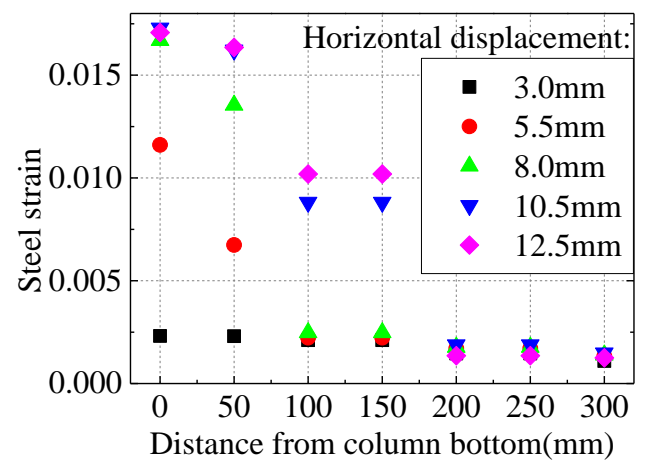

Figure 16: The distribution of steel tensile strain.

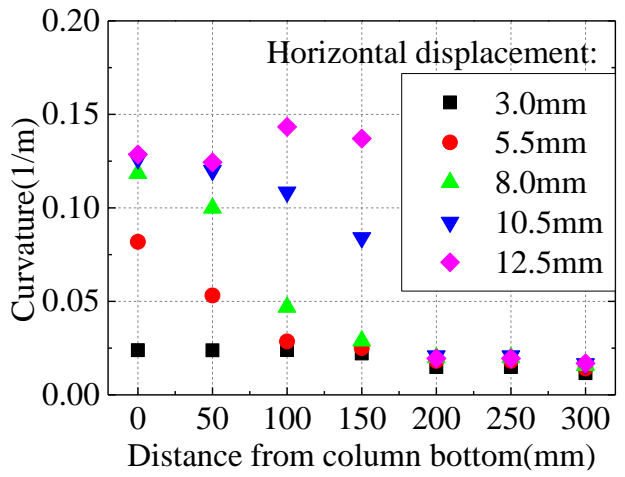

Figure 17: The distribution of sectional curvature.

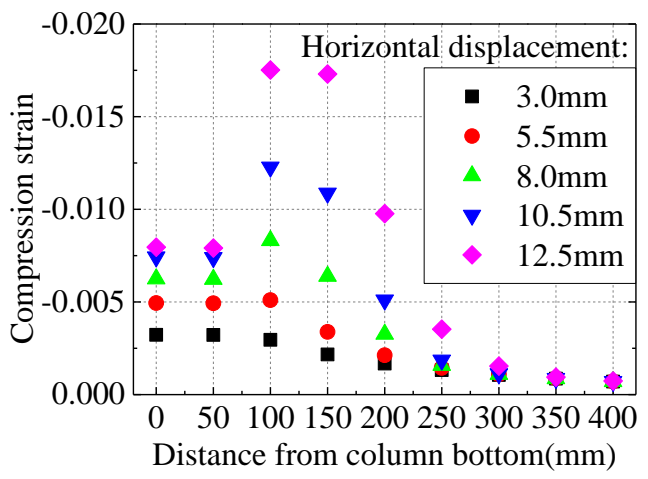

Figure 18: The distribution of concrete compressive strain.

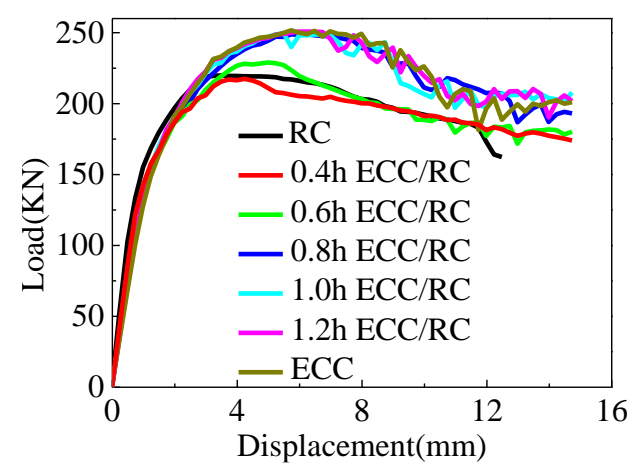

Figure 19: Load-displacement curves of calculated short columns.

\section{CONCLUSION}

This paper has presented the results of an experimental study on the seismic behaviors of ECC and ECC/RC composite short columns under reversed cyclic loading, and presented the results of a finite element analysis on the mechanical behaviors of these columns under combined vertical and horizontal loading. Based on the experimental and simulation results described in this paper, the following 
conclusions can be drawn:

1. For the RC short column specimen, the substitution of concrete with ECC in the column can transform the failure mode from brittle flexure-shear failure into flexural failure due to the high shear strength of ECC. Besides this, application of ECC in the column can prevent cover splitting and maintain structural integrity.

2. The ECC and ECC/RC composite column specimens have extremely similar seismic performance, including higher ductility and energy dissipation ability than $\mathrm{RC}$ column specimen, as well as less degradation in stiffness and load capacity. In view of cost performance, compared with ECC column, $\mathrm{ECC} / \mathrm{RC}$ composite column is more applicable in high seismic risk zones.

3. Small decrease of stirrup ratio in ECC/RC composite column specimens has no significant influence on the seismic behaviors. ECC can partly replace stirrups to reduce the stirrup ratio in columns, leading to more convenience in concrete casting.

4. In the ECC/RC composite short columns studied in this paper, the optimal height of ECC layer is $0.8 \mathrm{~h}$, which is equivalent to the height of plastic hinge regions of RC short column. Substitution of concrete with ECC in the plastic hinge regions of RC short column can achieve similar mechanical properties as the full ECC short column.

\section{REFERENCES}

[1] Boyd, P.F., Cofer, W.F., and Mclean, D.I. 1995. Seismic performance of steelencased concrete columns under flexural loading. ACI Structural Journal 92(3): 355-364.

[2] Aboutaha, R.S., and Machado, R. 1998. Seismic resistance of steel confined reinforced concrete (SCRC) columns. Structural Design of Tall Buildings 7(3): 251-260.

[3] Elremaily, A., and Azizinamini, A. 2002. Behavior and strength of circular concretefilled tube columns. Journal of Constructional Steel Research 58(12): 1567-1591.
[4] Varma, A.H., Ricles, J.M., Sause, R., et al. 2002. Seismic behavior and modeling of high-strength composite concrete-filled steel tube (CFT) beam-columns. Journal of Constructional Steel Research 58(01): 725-758.

[5] Seible, F., Priestley, M.J.N., Hegemier, G.A., et al. 1997. Seismic retrofit of RC columns with continuous carbon fiber jackets. Journal of composites for construction 1(2): 52-62.

[6] Sheikh, S.A., and Yau, G. 2002. Seismic behavior of concrete columns confined with steel and fiber-reinforced polymers. ACI Structural Journal 99(1): 72-80.

[7] Iacobucci, R.D., Sheikh, S.A., and Bayrak, O. 2002. Retrofit of square concrete columns with carbon fiber-reinforced polymer for seismic resistance. ACI Structural Journal 100(6): 785-794.

[8] Ozbakkaloglu, T., and Saatcioglu, M. 2014. Seismic Behavior of High-Strength Concrete Columns Confined by FiberReinforced Polymer Tubes. Journal of Composites for Construction 10(6): 538549.

[9] Parra-Montesinos, G.J. 2005. HighPerformance Fiber-Reinforced Cement Composites: An Alternative for Seismic Design of Structures. ACI Structural Journal 102(5): 668-675.

[10] Lee, H.H. 2008. Shear strength and behavior of steel fiber reinforced concrete columns under seismic loading. Steel Construction 29(7): 1253-1262.

[11] Billington, S.L., and Yoon, J.K. 2014. Cyclic response of unbonded posttensioned precast columns with ductile fiber-reinforced concrete. Journal of Bridge Engineering 9(4): 353-363.

[12] Osorio, L.I., Paultre, P., Eid, R., et al. 2014 Seismic behavior of synthetic fiberreinforced circular columns. ACI Structural Journal 111(1): 189-200.

[13] Kim, Y.Y., Fischer, G., and Li, V.C. 2004. Performance of bridge deck link slabs designed with ductile ECC. ACI Structural Journal, 101(6): 792-801.

[14] Lepech, M. D., and Li, V.C. 2009. 
Application of ECC for bridge deck link slabs. Materials \& Structures 42(9): 11851195.

[15] Lepech, M.D., and Li, V.C. 2010. Sustainable pavement overlays using engineered cementitious composites. International Journal of Pavement Research \& Technology 3: 241-250.

[16] Li, V.C. 2003. On engineering cementitious composites (ECC). Journal of Advanced Concrete Technology 1(3): 215230.

[17] Zhou, J.J., Pan, J.L. and Leung, C.K.Y. 2014. Mechanical behavior of fiberreinforced engineered cementitious composites in uniaxial compression. Journal of Materials in Civil Engineering 27(1): 1-10.

[18] Zhang, X.F., and Xu, S.L. 2008. Improvement of the flexural and cracking behavior of RC beams using ultra-high toughness cementitious composites (I): theoretical analysis. China Civil Engineering Journal 41(12): 48-54 (in Chinese).

[19] Fischer, G., and Li, V.C. 2002. Influence of matrix ductility on tension-stiffening behavior of steel reinforced engineered cementitious composites. ACI Structural Journal 99(1): 104-11.

[20] Yuan, F., Pan, J.L., Xu, Z., and Leung, C.K.Y. 2013. A comparison of engineered cementitious composites versus normal concrete in beam-column joints under reversed cyclic loading. Journal of Materials in Civil Engineering 46(1-2): 145-159.

[21] Fischer, G., and Li, V.C. 2002a. Influence of matrix ductility on ductility behavior of steel reinforced ECC flexural members under reversed cyclic loading condition. ACI Structural Journal 99(6): 781-790.

[22] Fischer, G., and Li, V.C. 2003. Intrinsic response control of moment resisting frames utilizing advanced composite materials and structural elements. ACI Structural Journal 100(2): 166-176.

[23] Li, V.C., and Wang, S. 2002. Flexural behaviors of glass fiber-reinforced polymer
(GFRP) reinforced engineered cementitious composite beams. ACI Structural Journal 99(1): 11-21.

[24] Yuan, F., Pan, J.L., Dong, L.T., and Leung, C.K.Y. 2014. Mechanical Behaviors of Steel Reinforced ECC or ECC/Concrete Composite Beams under Reversed Cyclic Loading. Materials \& Structures 46(12):145-159.

[25] Yuan, F., Pan, J.L., and Wu, Y.F. 2014. Numerical study on flexural behaviors of steel reinforced engineered cementitious composite (ECC) and ECC/concrete composite beams. Science China Technological Sciences 57(3):637-645.

[26] Červenka, V., Jendele, L., and Červenka, J. 2012. ATENA Program Documentation, Czech.

[27] Committee Euro-International Du Beton. 1993. CEB-FIB model code 1990: Design code, Thomas Telford, Lausanne. 